\title{
Pengaruh Pemberian Alkohol terhadap Gambaran Histopatologik Aorta Tikus Wistar (Rattus norvegicus) yang Diinduksi Margarin
}

\author{
${ }^{1}$ Kevin C. Kamalo \\ ${ }^{2}$ Lily L. Loho \\ ${ }^{2}$ Maria K. Sambuaga
}
${ }^{1}$ Program Studi Pendidikan Dokter Fakultas Kedokteran Universitas Sam Ratulangi Manado ${ }^{2}$ Bagian Patologi Anatomi Fakultas Kedokteran Universitas Sam Ratulangi Manado Email: kamalokevin@gmail.com

\begin{abstract}
Margarine is a kitchen ingredient that contains trans fat which plays an important role in the formation of atherosclerosis. Alcohol is one of the compounds that can slow down the formation of foam cells which are the beginning of atherosclerotic lesions. This study was aimed to determine the effect of alcohol administration on the aortic histopathological features of Wistar rats induced by margarine. This was an experimental laboratory study. Samples were 20 Wistar rats divided into 4 groups, as follows: negative control $(\mathrm{KN})$, given pellet only; positive control (KP), given pellet and margarine $5 \mathrm{~g}$ per day; treatment 1 (P1), given pellet, margarine $5 \mathrm{~g}$, and wine (14\% of alcohol) $0.18 \mathrm{ml}$ per day; and treatment 2 (P2), given pellet, margarine $5 \mathrm{~g}$, and wine $0.36 \mathrm{ml}$ per day. All samples were terminated at day 29 . Rat aortas were prepared for microscopic slides. The results showed that foam cells were found in the aortic layers. The highest number of foam cells was found in KP group, followed by P1 group, meanwhile P2 group had the lowest number of foam cells. Conclusion: In the aortas of Wistar rats given wine in moderate dose concomitantly with margarine (P1 and $\mathrm{P} 2$ groups), the numbers of foam cells were less than in Wistar rats that were given margarine only (KP group).
\end{abstract}

Keywords: wine, histopathology of aorta, atherosclerosis, margarine

\begin{abstract}
Abstrak: Margarin merupakan bahan dapur yang mengandung lemak trans yang sangat berperan dalam pembentukan aterosklerosis. Alkohol adalah salah satu senyawa yang dapat memperlambat pembentukkan sel busa yang merupakan awal dari lesi aterosklerosis. Penelitian ini bertujuan untuk mengetahui pengaruh dari pemberian alkohol terhadap gambaran histopatologik aorta tikus Wistar yang diinduksi margarin. Jenis penelitian ialah eksperimental laboratorik. Sampel penelitian ialah 20 ekor tikus Wistar yang dibagi atas 4 kelompok: kontol negatif (KN), hanya diberikan pelet; kontrol positif (KP) diberikan pelet dan margarin 5 gr per hari; perlakuan 1 (P1) diberikan pelet, margarin 5 gr dan minuman anggur (kandungan alkohol 14\%) $0,18 \mathrm{ml}$ per hari; dan perlakuan 2 (P2) diberikan pelet dan margarin 5 gr serta minuman anggur $0,36 \mathrm{ml}$ per hari. Semua sampel diterminasi pada hari ke-29, dan aorta tikus diambil untuk sediaan mikroskopik. Hasil pengamatan histopatologik mendapatkan sel busa pada lapisan-lapisan aorta dengan jumlah tertinggi pada kelompok KP, kemudian P1, dan paling sedikit pada P2. Simpulan: Pada tikus Wistar yang diberikan minuman anggur dosis moderat dan margarin secara bersamaan (P1 dan P2) terlihat sel busa yang lebih sedikit dibandingkan dengan tikus Wistar yang hanya diberikan margarine (KP).
\end{abstract}

Kata kunci: alkohol, histopatologik aorta, aterosklerosis, margarin

Hiperlipidemia merupakan salah satu faktor risiko utama terjadinya aterosklerosis.
Hiperlipidemia menyebabkan cedera sel endotel yang berperan dalam terjadinya 
aterosklerosis. Komponen kolesterol utama yang berkaitan dengan meningkatnya resiko aterosklerosis ialah kolesterol lowdensity lipoprotein (LDL). ${ }^{1}$

Aterosklerosis ditandai dengan adanya lesi pada lapisan intima yang disebut ateroma (atherosclerotic plaque), meninggi ke lumen pembuluh darah. ${ }^{2}$ Plak ateroma akan menyebabkan pembuluh darah menebal dan lumennya menjadi sempit. Penyempitan lumen pembuluh darah akan menyebabkan penurunan pasokan oksigen pada organ target yang berada di bagian distal. Plak tersebut tersusun dari lemak, kolesterol, kalsium, dan fibrin yang ditutupi jaringan ikat. ${ }^{2-4}$

Margarin adalah selai mentega tiruan yang digunakan untuk pemanggangan dan memasak. ${ }^{5}$ Margarin, seperti mentega, terdiri dari emulsi air dalam lemak, dengan tetesan kecil air yang tersebar merata di seluruh fase lemak dalam bentuk kristal yang stabil. ${ }^{6}$ Sebagaimana halnya mentega, margarin harus memiliki kandungan lemak minimum $80 \%$ untuk bisa diberi label margarin. ${ }^{7}$ Margarin mengandung asam lemak trans yang dapat meningkatkan kadar kolesterol LDL dan menurunkan kadar kolesterol high-density lipoprotein (HDL). Studi prospektif pada 71.410 wanita yang berusia 50-79 tahun, dengan mengevaluasi infark miokard (MI) secara klinis, penyakit jantung koroner total (PJK), stroke iskemik, dan aterosklerosis terkait cardiovascular disease (CVD), mendapatkan peningkatan PJK, stroke iskemik, dan CVD yang disebabkan aterosklerosis pada penggunaan margarin. ${ }^{8}$

Etanol ialah komposisi utama dalam minuman beralkohol. Etanol merupakan bahan kimia neuroaktif yang bersifat simultan sistem saraf pusat (SSP), dan memiliki pola metabolik unik yang relatif terhadap sumber kalori lainnya (makronutrien, karbohidrat, protein, dan lemak diet). ${ }^{9}$ Pola mengonsumsi alkohol juga dikatakan dapat memberi perlindungan yang dimediasi oleh modulasi dari faktor risiko lain karena alkohol dapat meningkatkan high-density lipoprotein cholesterol (HDL-C), dan memodulasi fungsi endotel, serta tidak meningkatkan berat badan atau merusak homeostasis glukosa-insulin. ${ }^{10}$ Mengonsumsi etanol dengan dosis rata-rata serta berolahraga dapat meningkatkan kadar HDL. ${ }^{2}$

Penelitian ini bertujuan untuk mendapatkan pengaruh alkohol dan margarin terhadap gambaran histopatologik aorta tikus Wistar.

\section{METODE PENELITIAN}

Jenis penelitian ini ialah eksperimental laboratorik yang dilakukan di Laboratorium Patologi Anatomi Fakultas Kedokteran Universitas Sam Ratulangi Manado. Subjek penelitian yang digunakan ialah 20 ekor tikus Wistar (Rattus norvegicus) dewasa yang dibagi dalam kelompok kontrol dan kelompok perlakuan.

Setiap kelompok diberi perlakuan berbeda dan diberikan makanan pelet AD2 dan minuman yang sama setiap hari selama pengujian. Kelompok kontrol negatif (KN) hanya diberikan pelet. Kelompok kontrol positif (KP) diberikan pelet dan margarin 5 gr per hari. Kelompok perlakuan 1 (P1) diberikan pelet, margarin $5 \mathrm{gr}$, dan minuman anggur 0,18 $\mathrm{ml}$ per hari. Kelompok perlakuan 2 (P2) diberikan pelet dan margarin $5 \mathrm{gr}$, serta minuman anggur 0,36 $\mathrm{ml}$ per hari. Minuman anggur yang dipakai ialah anggur cap Orang Tua dengan kadar alkohol 14\%. Masing-masing kelompok diberi perlakuan selama 28 hari dan diterminasi pada hari ke-29 dengan diisi ke dalam toples berisi kapas yang sudah ditetesi eter. Aorta tikus Wistar yang telah diotopsi kemudian difiksasi dalam larutan formalin $10 \%$, setelah itu dibuat sediaan lalu diamati di bawah mikroskop cahaya.

\section{HASIL PENELITIAN}

Penelitian ini menggunakan 20 ekor tikus Wistar. Semua tikus diterminasi pada hari ke-29. Aorta tikus diambil dan dibuat sediaan mikroskopik. Tikus Wistar pada kelompok kontrol negatif $(\mathrm{KN})$ terdiri dari 5 ekor tikus, yang hanya diberikan pakan pelet AD2 selama 28 hari. Gambaran mikroskopik ketiga lapisan aorta, yaitu tunika intima, tunika media dan tunika 
adventisia terlihat normal (Gambar 1).

Kelompok kontrol positif (KP) terdiri dari 5 ekor tikus dan diberi pakan pelet AD2 serta diinduksi dengan margarin selama 28 hari. Pada gambaran histopatologik ditemukan adanya sel busa pada tunika intima dan tunika media (Gambar 2).

Kelompok perlakuan 1 (P1) terdiri dari 5 ekor tikus Wistar yang diberikan pakan pelet AD2 dan margarin bersamaan dengan minuman anggur $0,18 \mathrm{ml}$ selama 28 hari. Pada gambaran histopatologik terlihat adanya sel busa dalam tunika intima dan tunika media namun jumlahnya lebih sedikit dibandingkan dengan kelompok KP (Gambar 3 dan 4).

Kelompok perlakuan $2(\mathrm{P} 2)$ terdiri dari 5 ekor tikus yang diberikan pakan pelet AD2 dan margarin bersamaan dengan minuman anggur $0,36 \mathrm{ml}$ selama 28 hari. Pada gambaran mikroskopik didapatkan adanya sel busa dalam tunika intima namun lebih sedikit dibandingkan dengan kelompok KN dan kelompok P1 (Gambar 5 dan 6).

\section{BAHASAN}

Minuman anggur memiliki 2 jenis efek protektif yaitu peningkatan HDL-C oleh alkohol dan flavonoid yang dikandung oleh anggur. Alkohol memiliki efek protektif terhadap aorta dengan cara meningkatkan HDL-C serta menurunkan LDL. ${ }^{11-13}$ Pemberian minuman anggur juga berefek protektif terhadap lesi aterosklerosis seperti yang sudah dijelaskan sebelumnya yaitu oleh senyawa flavonoid yang berefek antioksidan. ${ }^{14}$

Pada tikus kelompok kontrol negatif $(\mathrm{KN})$ terlihat gambaran mikroskopik aorta normal tanpa adanya lesi aterosklerosis. Pada kelompok ini dapat terlihat lapisanlapisan aorta yang masih utuh layaknya gambaran mikroskopik normal aorta. Pada kelompok ini tidak terdapat sel busa dikarenakan kelompok ini hanya diberikan pakan pelet AD2 dan minum.

Pada tikus kelompok kontrol positif (KP) didapatkan gambaran mikroskopik dengan adanya banyak sel busa dalam lapisan tunika intima, tunika media, dan tunika adventisia. Pemberian margarin dalam dosis yang melebihi normal pada tikus mengakibatkan terbentuknya sel busa dalam lapisan-lapisan aorta. Margarin memiliki lemak trans yang dapat meningkatkan pembentukan lesi aterosklerosis. Margarin meningkatkan LDL dan menurunkan HDL. Selain itu margarin dapat mengakibatkan cedera sel endotel pada aorta yang merupakan mekanisme awal dari proses terbentuknya aterosklerosis. Ketika terjadi cedera sel endotel, monosit akan beremigrasi dari aliran darah ke tunika intima dan berdiferensiasi menjadi makrofag yang menghasilkan radikal bebas dan bersama LDL akan membentuk LDL teroksidasi. LDL teroksidasi akan di fagosit oleh makrofag dan menjadi sel busa. Oleh sebab itu pemberian margarin dalam rentang waktu yang lama dapat mengakibatkan terbentuknya sel busa dan akan menuju pada aterosklerosis. ${ }^{11-13}$

Pada kelompok perlakuan 1 (P1) dengan jumlah 5 ekor tikus didapatkan gambaran mikroskopik adanya sel busa dalam tunika intima dan tunika media namun lebih sedikit dibandingkan dengan kelompok KP tetapi pada sebagian tikus masih terdapat banyak sel busa. Kelompok P1 diberikan pakan pelet AD2 dan margarin bersamaan dengan alkohol $0,18 \mathrm{ml}$ yang dalam hal ini minuman anggur. Berkurangnya sel busa disebabkan oleh peran alkohol yaitu meningkatkan HDL-C sehingga proses pembentukan sel busa akan melambat. HDL-C berperan dalam menghambat penimbunan kolesterol LDL. ${ }^{11-13}$

Kelompok P2 diberi perlakuan yang mirip dengan kelompok P1 namun dosis alkohol sebesar 0,36 ml yaitu dosis moderat konsumsi manusia. ${ }^{15,16}$ Gambaran mikroskopik memperlihatkan sel busa yang sangat sedikit dibandingkan kelompok P1 dan KP tetapi pada sebagian tikus masih terdapat banyak sel busa. Dosis moderat akan lebih berperan dalam menghambat proses aterosklerosis berdasarkan kurva berbentuk J, dimana dosis rendah dan tinggi alkohol akan lebih berisiko terbentuknya lesi aterosklerosis. ${ }^{11-13}$ 


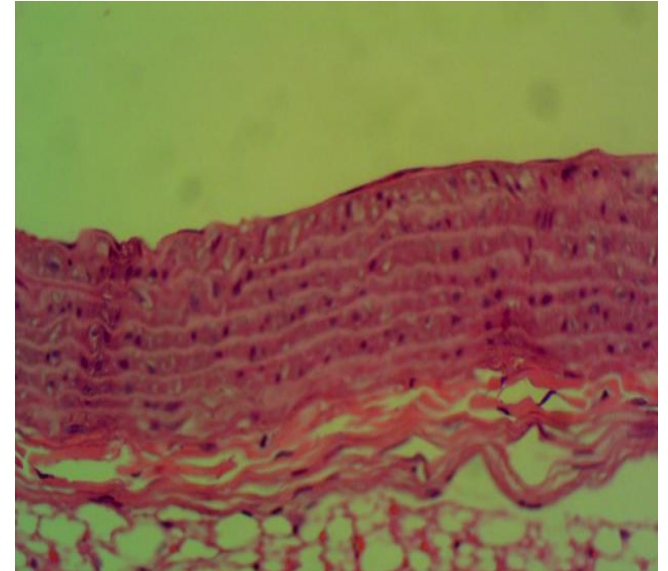

Gambar 1. Gambaran mikroskopik potongan melintang aorta tikus Wistar kelompok KN pembesaran 40x10. Tidak terdapat sel busa dalam tunika intima, tunika media. dan tunika adventisia

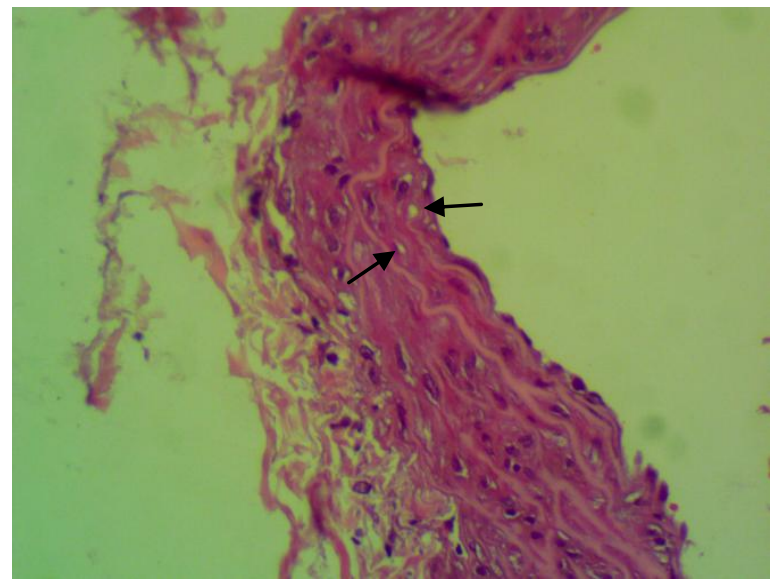

Gambar 3. Gambaran mikroskopik potongan melintang aorta tikus Wistar kelompok P1 (pembesaran 40x10). Terlihat sedikit sel busa dalam tunika intima dan tunika media

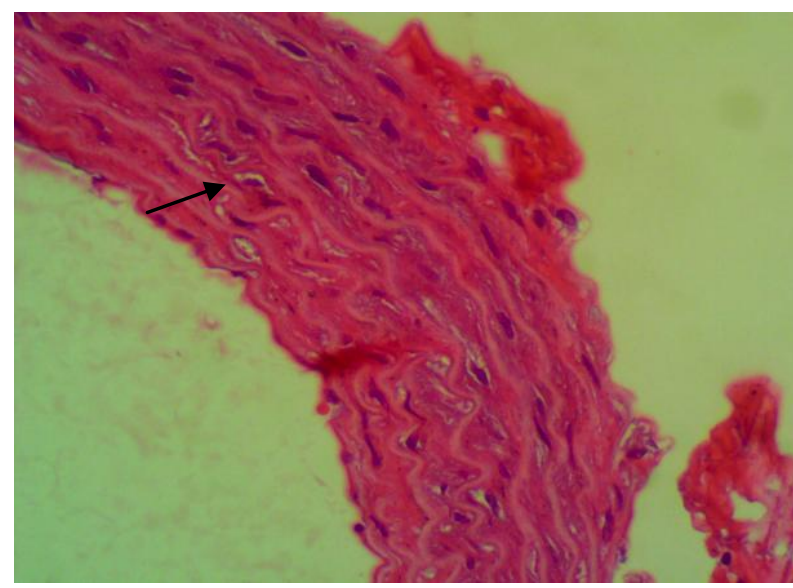

Gambar 5. Gambaran mikroskopik potongan melintang aorta tikus Wistar kelompok P2 (pembesaran 40x10). Terlihat sedikit sel busa dalam tunika intima

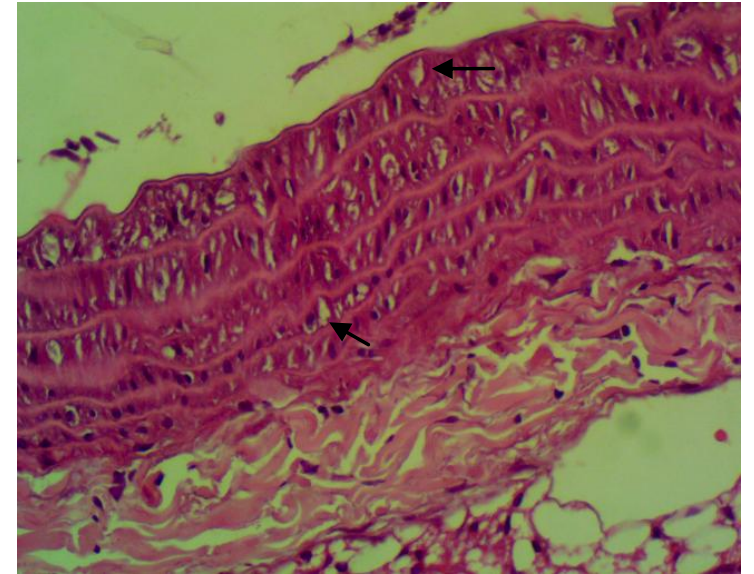

Gambar 2. Gambaran mikroskopik potongan melintang aorta tikus wistar kelompok KP (pembesaran 40x10). Terlihat sel busa dalam tunika intima dan tunika media.

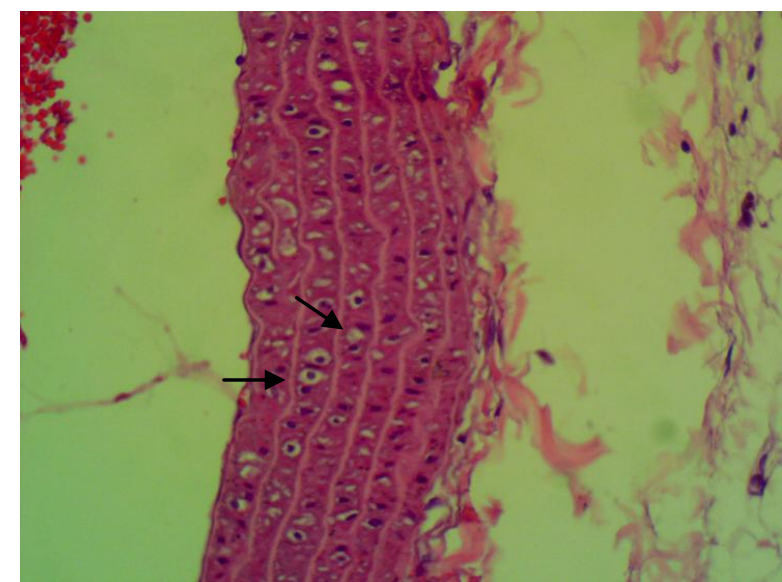

Gambar 4. Gambaran mikroskopik potongan melintang aorta tikus Wistar kelompok P1 (pembesaran 40x10). Terlihat sel busa yang lebih banyak dalam tunika intima dan tunika media.

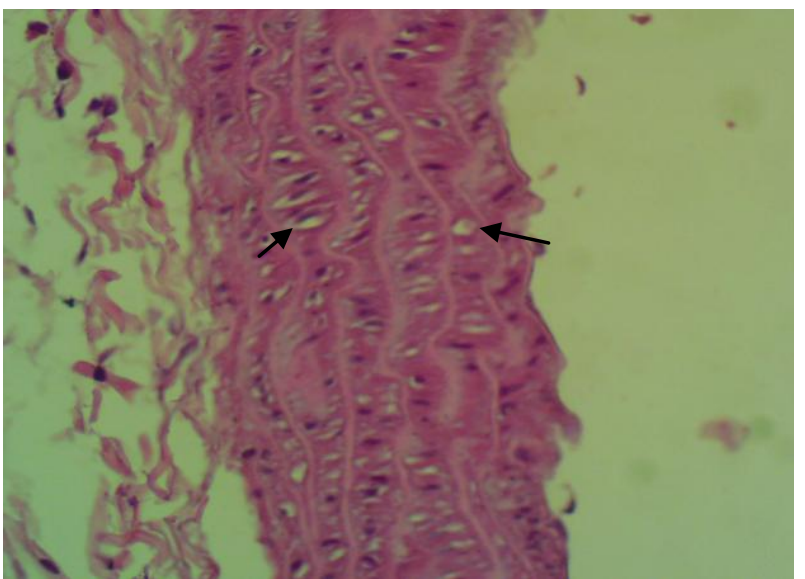

Gambar 6. Gambaran mikroskopik potongan melintang aorta tikus Wistar kelompok P2 (pembesaran 40x10). Terlihat sel busa yang lebih banyak dalam tunika intima dan tunika media 
Flavonoid merupakan antioksidan yang juga berperan mengurangi radikal bebas yang akan berinteraksi dengan LDL, serta mengurangi regulasi TNF- $\alpha$, VCAM-1, dan ICAM-1 yang akan semakin menghambat proses aterosklerosis.

Berdasarkan gambaran mikroskopik dari kelompok KP, P1, dan P2 didapatkan perubahan jumlah sel busa dalam lapisan aorta berbeda-beda. Pada kelompok KP lebih banyak didapatkan sel busa, sedangkan pada kelompok P1 lebih sedikit sel busa dibandingkan dengan kelompok KP. Pada kelompok P2, sel busa hanya pada tunika intima dan lebih sedikit dibandingkan dengan kelompok P1. Dengan demikian dapat diasumsikan bahwa pemberian alkohol dapat memengaruhi pembentukan sel busa pada aorta tikus Wistar yang diinduksi margarin pada sebagian tikus.

\section{SIMPULAN}

Berdasarkan hasil penelitian ini dapat disimpulkan bahwa tikus Wistar (Rattus norvegicus) yang diberikan margarin dan minuman anggur memperlihatkan jumlah sel busa pada lapisan aorta yang lebih sedikit dibandingkan tikus Wistar yang hanya diberikan margarin.

\section{SARAN}

Perlu dilakukan penelitian lanjut untuk mengevaluasi efek mengonsumsi alkohol terhadap proses aterosklerosis dengan dosis dan waktu yang berbeda.

\section{DAFTAR PUSTAKA}

1. Kumar V, Abbas AK, Aster JC. Pembuluh darah. In: Saraswati M, editor. Buku Ajar Patologi Robbins (9th ed). Singapura: Elsevier Saunders, 2015; p. 321-58.

2. Kumar V, Abbas AK, Fausto N, Aster JC. Blood vessels. In: Mitchell RN, editor. Robbins and Cotran Pathologic Basis of Disease (8th ed). Saunders Elsevier, 2010; p. 496-502.

3. Srividya. Atherosclerosis-coronary heart disease and the recent advancements in the treatment of atherosclerosis. Journal of Medical and Health Sciences. 2017; 6:1-9.
4. Penyakit aterosklerotik koroner. In: Price SA, Wilson LM, editors. Patofisiologi: Konsep Klinis Proses-Proses Penyakit Volume 1 (6th ed). Jakarta: ECG, 2005; p. 576-612.

5. Rupp R. The butter wars: when margarine was pink. The Plate: National Geographic, 2017.

6. Rajah K. Spread thickly with innovation: with the basic concept of spreads unchanged for decades, producers have to be increasingly innovative in their product development and marketing. Kanes Rajah outlines some successful strategies. Al Business website. The Gale Group, Inc. 2009.

7. Subpart B. Requirements for specific standardized margarine. Code of Federal Regulations. Food for Human Consumption. US Food and Drug Administration, 2017; p. 21.

8. Liu Q, Rossouw JE, Roberts MB, Liu S, Johnson KC, Shikany JM, et al. Theoretical effects of substituting butter with margarine on risk of cardiovascular disease. Epidemiology. 2017; 28:145-56.

9. Hansen CS, Faerch LH, Kristensen PL. Testing the validity of the Danish urban myth that alcohol can be absorbed through feet: open labelled self experimental study. BMJ. 2010; 341:c6812. doi: 10.1136/bmj.c6812.

10. Foppa M, Fuchs FD, Duncan BB. Alcohol and atherosclerosis. Arq. Bras. Cardiol. 2001;76(2):171-6.

11. Mahajan H, Choo J, Masaki K, Fujiyoshi A, Guo J, Hissamatsu I, et al. ,Association of alcohol consumption and aortic calcification in healthy men aged 40-49 years for the ERA JUMP study. Atherosclerosis. 2018;268:84-91.

12. Kim MK, Shin J, Kweon SS, Shin DH, Lee YH, Chun BY, et al. Harmful and beneficial relationship between alcohol consumption and subclinical atherosclerosis. Nutr Metab Cardiovasc Dis. 2014;24:767-76.

13. Kelso-Chichetto NE, Plankey M, Sheps DS, Abraham AG, Chen X, Shoptaw S, et al. The impact of long-term moderate and heavy alcohol consumption on incident atherosclerosis among persons living with HIV. Drug alcohol Depend. 2017;181:235-41. 
194 Jurnal e-Biomedik (eBm), Volume 6, Nomor 2, Juli-Desember 2018

14. Perez FV, Duarte J. Flavonols and cardiovascular disease. Molecular Aspects of Medicine. 2010;31:478-94.

15. Brunton LL, Dandan RH, Knollmann BC. Goodman \& Gilman's The Pharmaco- logical Basis of Therapeutics (13th ed). New York: McGrawHill, 2013.

16. Laurence DR, Bacharach AL. Evaluation of Drug Activities (1st ed). New York: Saunders Elsevier, 1964 